\title{
NACJONALIZM W PRZEMÓWIENIACH SLOBODANA MILOŠEVICIA
}

$R$ ozpad Jugosławii ujawnit zadawnione problemy ekonomiczne, polityczne, narodowościowe, kulturowe i ideologiczne. W wyniku tych procesów w latach osiemdziesiątych w Jugosławii doszło do odrodzenia ukrywanych nacjonalizmów: słoweńskiego, chorwackiego, serbskiego, macedońskiego, muzułmańskiego i albańskiego. Serbski nacjonalizm był kombinacją religijno-etnicznej tożsamości ${ }^{1}$. Kształtowany był także przez serbskie historyczne mity utrwalane na przestrzeni dziejów, takie jak: kult świętego Sawy - założyciela serbskiego Kościoła prawosławnego, bitwa na Kosowym Polu z 1389 r. i związane z tym kosowskie męczeństwo oraz legenda księcia Lazara. Innymi kwestiami, które pomagały zdefiniować serbskość były: Slava - święto patrona rodziny, dialekt sztokawski, prawosławie, średniowieczna dynastia Nemanjiciów, dokonania Car Dušana, XIV-wiecznego władcy Serbii i Grecji, wielkie migracje Serbów z XVII i XVIII wieku oraz serbskie powstania przeciw Turkom z lat 1804 i 1815². Wpływ na kształtowanie narodowej ideologii miały dwie wojny bałkańskie z lat 1912-1913, z których pochodzi określenie Serbii jako Piemontu narodów. Ponadto typem wspólnoty wyobrażonej było państwo jugosłowiańskie, w którym Serbowie trzech religii, prawosławnej, katolickiej i islamskiej, mogli czuć się zjednoczeni terytorialnie i złączeni jednym językiem serbsko-chorwackim³.

Niniejszy artykut ma na celu przeanalizowanie retoryki Slobodana Miloševicia, w przemówieniach z lat 1988-1992, w których przywódca Federacyjnej Repub-
Dr Anna JAGIELtO-SZOSTAK jest adiunktem w Katedrze Europeistyki w Wyższej Szkole Handlowej we Wroctawiu. annajagiello83@gmail.com

1 D.T. Bataković, Tipovi nacionalizma kod Hrvata i Srba u Hrvatskoj: sličnosti i razlike, w: H-G Fleck, I. Graovac (red.), Dijalog povjesničara- istoričara, br. 2, Zagreb 2000, s. 201-202.

2 A. Pavković, The Fragmentation of Yugoslavia. Nationalism in a Multinational State, Sydney 1996, s. 6-10.

3 D.T. Bataković, op. cit., s. 203-204. 
liki Jugosławii (FRJ) wykorzystał część nacjonalistycznych motywów. Cezura czasowa dotyczy początku dochodzenia przywódcy serbskiego do władzy (1988) i uchwalenia nowej konstytucji FRJ (1992). Wybrane przemówienia ${ }^{4}$ wygłaszane były przez S. Miloševicia w parlamencie Serbii (Skupština), na posiedzeniach Socjalistycznej Partii Serbii oraz na kierowanych do narodu wiecach i mitingach w miastach takich, jak: Gazimestan, Belgrad, Nowy Sad, Bor i Niš. W artykule przedstawiona zostanie analiza najważniejszych kwestii poruszanych przez S. Miloševicia. Należą do nich problem rozbicia Jugosławii i kwestia postrzegania przez przywódcę Serbii i Serbów, Kosowa oraz przeciwników prezydenta, do których w tym okresie należały Albania, Chorwacja i Słowenia.

\section{SYLWETKA SLOBODANA MILOŠEVICIA}

Sylwetka jugosłowiańskiego, a później serbskiego prezydenta Slobodana Miloševicia ${ }^{5}$ budzi wiele kontrowersji. Po śmierci Josipa Broz Tity w 1980 r. społeczeństwo, które wydawało się zadowolone z pozbycia się autorytarnego przywódcy, czuło się - jak pisze Slavenka Drakulić - osamotnione i przestraszone: „osierocony naród potrzebował nowego ojca", kogoś, kto się nim zajmie ${ }^{6}$. Polityk ten łatwo dotarł na szczyt władzy, posługując się chwytliwymi hasłami: "Nikt was już nie będzie bił" - słowa te padły na wiecu na Kosowym Polu w 1987 r. i uczyniły go bohaterem narodowym. Nowy przywódca zaznaczał, że „,bez Kosowa Jugosławia się rozpadnie. Jugosławia i Serbia nigdy nie wyrzekną się Kosowa". Był pierwszym belgradzkim politykiem, który publicznie mówił to, co mieszkańcy serbskich prowincji podkreślali już od dawna. Obywatele prosili go, by pomścił ciągłe upokorzenie szlachetnej Serbii w bogatszych, lecz cudzoziemskich prowincjach Chorwacji i Słowenii, by pomścił I u d o b ó j s t w o na terytoriach muzułmańskich, którego ofiarą padła przymusowo asymilowana mniejszość serbska i prawosławna w Kosowie i Bośni, by położył kres niesprawiedliwej dystrybucji funduszy federalny ch. Postulaty te już wcześniej częściowo zawarte były w Memorandum Serbskiej Akademii Nauk i Sztuk z 1986 r. (choć napisane nie tak radykalnym językiem) i stały się deklaracją ideową nowego nacjonalizmu serbskiego ${ }^{7}$.

Polityk serbski 8 maja 1989 r. wybrany został na prezydenta Republiki Serbii w Jugosławii. Z kolei w przedwyborczej kampanii w 1989 r. Serbska Partia Socjalistyczna (której był członkiem) wystąpiła z hasłem Silna Serbia w silnej Jugosławii (Snažna Srbija u snažnoj Jugoslaviji). W 1990 r. wybrano go na nowego przewodniczącego partii komunistycznej, przemianowanej na Socjalistyczną Partię Serbii (SPS). W jej programie miejsce ko-

\section{......}

4 Tytuły przemówień brzmią następująco: Miting bratstva i jedinstva u Beogradu, Govor na Gazimestanu, Govor na sednici predsedništva SR Srbije - Izbor za predsednika, Govor na skupštini Srbije - izbor za predsednika predsedništva SR Srbije, Govor na predsedništvu SRS, Govor u Boru, Govor na mitingu u Nišu, Govor na mitingu u Novom Sadu, Govor na Skupštini Srbije, Govor u Skupštini Srbije i Govor u Skupštini SRJ prilikom proglašenja Ustava SRJ.

5 Slobodan "Slobo" Milošević urodzit się 29.08.1941 r. w Požarevcu w Serbii. W czasie studiów prawniczych w 1959 r. zapisał się do partii komunistycznej i został przewodniczącym komisji ideologicznej komitetu partyjnego Uniwersytetu w Belgradzie. Następnie pracował w przemyśle. W 1969 r. został wicedyrektorem, a w 1974 r. dyrektorem generalnym Technogazu. Od 1978 r. był dyrektorem belgradzkiego Beobanku. Do polityki wciągnął go kolega ze studiów Ivan Stambolić, który później został prezydentem Serbii. Od 1984 r. S. Milošević przejął po nim stanowisko miejskiego sekretarza partii w Belgradzie, a w 1987 r., w wieku 45 lat, został sekretarzem Komunistycznej Partii Serbii, co uczyniło go przywódcą wszystkich partii komunistycznych w krajach dawnej federacji jugosłowiańskiej. A. Koseski, W bałkańskim tyglu, Pułtusk 2002, s. 174, 178 i R. Orizio, Diabet na emeryturze. Rozmowy z siedmioma dyktatorami, Poznań 2004, s. 178-180.

6 S. Drakulić, Oni nie skrzywdziliby nawet muchy. Zbrodniarze wojenni przed Trybunałem w Hadze, Warszawa 2006, s. 144-145.

7 Memorandum Srpske akademije nauka i umetnosti, Beograd 1986. 
munizmu zajął nacjonalizm, co widoczne było też w jego przemówieniach. W 1991 r. dochodziło do wielu protestów studentów, którzy chcieli by "Slobo" wprowadził demokratyczne reformy. Rząd użył wtedy policji do rozproszenia demonstracji. Według S. Miloševicia było to przeciwstawienie się s i to m c h a o s u. Kiedy okazało się, że Chorwacja nie chce pozostać przy Jugosławii, przywódca coraz częściej wspominał, iż Serbowie powinni mieszkać w jednym państwie ${ }^{8}$. Dlatego też próbował przeciwstawić się niepodległości republik jugosłowiańskich: Chorwacji, Słowenii i Bośni i Hercegowiny oraz silnie nakreślał problem Kosowa.

\section{O JUGOStAWII}

W analizowanych tekstach z początku badanego okresu jedną z najczęściej powtarzających się kwestii jest Jugosławia. Mówił o niej jako o osiągnięciu wojennym, pracy i miłości wszystkich jugosłowiańskich narodów i narodowości. Dla niego solidarność jugosłowiańskich narodów od zawsze była najsilniejszą i najpiękniejszą ich cechą.

Wzywał do przebudzenia serc, odświeżenia pamięci i zjednoczenia sił po to, by zachować Jugosławię - Jugosławię Tity (stworzoną przez komunistów). Mówił też o niej jako o wspólnej ojczyźnie, która funkcjonowała pomimo problemów, a teraz jest zagrożona idea i realizacja Jugosławii, niebezpieczeństwo rozpadu stoi u jej bram.

„Dzisiaj, kiedy niewola dosięgnęła Jugosławię, wszyscy razem podnieśmy głos, obudźmy serce, wykorzystajmy pamięć i zjednoczmy siły, by zachować swoją ziemię. Jugosławię Tity, w wielkiej rewolucji, stworzyli jugosłowiańscy komuniści, jugosłowiańska klasa pracująca i jugostowiańskie narody"10.

Postrzegał ją jako wielonarodowościową wspólnotę, która może istnieć w warunkach równości wszystkich nacji, które ją zamieszkują. Jest także optymalnym rozwiązaniem kwestii narodowej jugosłowiańskich grup narodowych:

„Jugosławia jest wielonarodowościową wspólnotą i tylko ona może utrzymać warunki całkowitej równoprawności wszystkich narodów, które ją zamieszkują"11.

„Jugosławia jest bez wątpienia optymalnym rozwiązaniem kwestii narodowej wszystkich narodów jugostowiańskich..."12.

Analizowany tekst daje także odpowiedź na pytanie, jakie było jego stanowisko dotyczące rozpadu Jugosławii. Uważał, że kryzys doprowadził do podziałów narodowych, społecznych, kulturowych. Za niesprawiedliwe uważat, iż wspólnota międzynarodowa obarczała Serbię winą za wywołanie wojny i postrzegała ją jako głównego agresora. Według niego Serbia broniła prawa do życia narodu serbskiego we wspólnym państwie. Twierdził także, że prawo narodu do wyjścia z Jugosławii nie może być silniejsze od prawa narodu do zostania w niej. Dodawał, że gdyby pod przymusem Serbia dopuściła się secesji, wtedy utrudnione byłoby zachowanie serbskich żywotnych interesów ${ }^{13}$.

\section{......}

8 J. Guskova, Istorija jugoslavenske krize 1990-2000, t. 1, Beograd 2003, s. 124, 127, 200

I.B. Mijatović, Koreni vojne pisane reči, Beograd 2006, s. 222, 224. Govor na sednici predsedništva SR Srbije - izbor za predsednika, w: S. Milošević, Prolog istoriji dvadesetog veka, Beograd 2008, s. 18; Govor u Boru, w: S. Milošević, op. cit., s. 68.

10 I.B. Mijatović, op. cit., s. 224. Tłumaczenia fragmentów tekstów dokonała autorka.

11 Govor na sednici predsedništva SR Srbije - izbor za predsednika, w: S. Milošević, op. cit., s. 18

12 Govor u skupštini Srbije, w: S. Milošević, op. cit., s. 129.

13 Govor na sednici predsedništva SR Srbije - izbor za predsednika, w: S. Milošević, op. cit., s. 25; Govor u skupštini Srbije, w: S. Milošević, op. cit., s. 127. 
„Wspólnota międzynarodowa nie była sprawiedliwa wobec wojny i wydarzeń w Jugosławii, i oczywiście w Serbii ${ }^{14}$. Pokazywanie Serbii jako agresora było nieprawdziwe i nieodpowiednie. Minęło wiele miesięcy i trudu, by wyjaśnić światu, a zwłaszcza Europie, że Serbia nie wywołała wojny i jej też nie chce"15.

W jego przemówieniach nieustannie widzimy chęć utrzymania Jugosławii. Za niezbędny warunek zachowania Jugosławii uważał Milošević równość i zgodność między narodami, a jej istnienie zależało od wszystkich narodowości żyjących na jej terytorium. Dodatkowo zachowanie politycznej podmiotowości Jugosławii, nawet pomniejszonej, było warunkiem większej stabilności na Bałkanach:

„Równoprawność i zgoda między narodami jugosłowiańskimi są koniecznym warunkiem do utrzymania Jugosławii, wyjścia z kryzysu państwowego, i do jej ekonomicznego i społecznego rozwoju"16.

"Jugosławia zależy od nas wszystkich [...], którzy są zgodni i zjednoczeni"17.

„Potwierdzone jest, iż utrzymanie Jugosławii, chociażby w pomniejszonej formie, przyniesie większą stabilność na Bałkanach niż jej podział"18.

Jugosławia według niego była także bytem, który idealnie rozwiązuje kwestię serbską, ponieważ gromadzi większość Serbów w jednym państwie - jest to jeden z warunków dlaczego Republika Serbii broni jedności Jugosławii:

„[...] Jugosławia jest projektem państwowym, który prawie idealnie rozwiązuje serbską kwestię narodową: ponieważ skupia największą liczbę Serbów w jednym państwie. Z tych powodów naród serbski przyjął Jugosławię do niezależnego państwa Serbskiego. Dziś jest to, teoretycznie i praktycznie, lepszy wariant rozwiazania serbskiej kwestii narodowej"19.

\section{O SERBII}

Kolejny temat poruszany przez S. Miloševicia to Serbia i naród serbski. W kontekście tym często używał słowa "sloga” - "zgoda”. Widzimy tu nawiązanie do motta serbskiego: "Tylko zgoda zbawi Serba” - „Samo sloga Srbina spašava”, które używane było między innymi przeciw obcej dominacji. J. Guskova przytacza słowa Adila Zulfikarpašicia ${ }^{20}$, który twierdzit, iż S. Milošević wstąpit na scenę polityczną jako ten, który chciał zburzyć Jugosławię i próbował utworzyć z Jugosławii hegemonistyczną Wielką Serbię ${ }^{21}$. Prześledzenie treści przemówień pozwoliło ustalić, że S. Milošević mówił o Serbii jako wielkim kraju, często wspominał przeszłość, zwłaszcza tę, kiedy Serbia święciła sukcesy. Wśród wszystkich poruszanych kwestii w przemówieniach Serbia zdaje się być najważniejsza, jednolita i silna, tak że nikt nie rzuci jej na kolana. Warunkiem utrzymania Serbii jest zasiedlanie Kosowa przez ochotników - nawoływał do mobilizacji na rzecz Kosowa i Serbii:

„Szczególnie dzisiaj, gdy mamy jednolitą Serbię, nie istnieje zagrożenie rzucenia jej przez kogokolwiek na kolana [...]. Ale istnieje potrzeba ochotników - ochotników do życia w Kosowie [...]. Oni powinni iść [...] na południe z wielką misją pracy, pokoju i odnowy części Serbii i Ju-

14 Govor u skupštini Srbije, w: S. Milošević, op. cit., s. 126.

15 Ibidem.

16 Govor na sednici predsedništva SR Srbije - izbor za predsednika, w: S. Milošević, op. cit., s. 25.

17 Ibidem, s. 18.

18 Govor u skupštini Srbije, w: S. Milošević, op. cit., s. 128.

19 Ibidem, s. 130.

20 Były wiceprezydent Bośni i Hercegowiny.

21 J. Guskova, op. cit., s. 52. 
gosławii, które są dręczone przez przemoc i biedę. Pamięć, ręce i determinacja tych ochotników są dzisiaj konieczne dla Kosowa i Serbii. W Serbii i całej Jugosławii potrzebna jest mobilizacja dla Kosowa"22.

Ponadto Serbia wspiera istnienie Jugosławii, ponieważ na jej terenie mieszka wielu Serbów i to właśnie spośród nich pochodzi największa liczba tych, którzy walczyli i ginęli za Jugosławię. Według niego Serbia jest także gotowa, aby kontynuować pamięć i spuściznę po Jugosławii i popiera Jugosławię jako federalną wspólnotę i nie dopuści do przemocy w stosunku do narodu serbskiego zamieszkującego poza granicami Serbii ${ }^{23}$ :

„Serbia widzi Jugosławię jako federalną wspólnotę z wielu przyczyn. Po pierwsze, Serbowie zamieszkują całą Jugosławię. Pokojowa, demokratyczna droga do wykonania tego celu to jugostowiańska federacja. Państwo, w którym narody i ludzie są równoprawni. Rozsądnie i uporczywie, drogą pokoju i demokracji walczyć będziemy o rozwiązanie serbskiej kwestii narodowej w Jugosławii. W tym samym czasie nie dopuścimy przemocy wobec serbskiego narodu poza Serbią" 24

Wśród celów przyświecających Serbii wymienia między innymi rozwój ekonomiczny, polityczny i kulturalny narodu serbskiego, przywrócenie godności poprzez odnowienie zgody w społeczeństwie. Serbia jest nosicielem procesów integracyjnych w Jugosławii i jest to synonim stabilności na Bałkanach, w swoich rękach trzyma teraźniejszość i przyszłość i to od niej zależy, czy będzie się rozwijać, czy też nie ${ }^{25}$.

„[...] odnowiona zgoda może ulepszyć (Serbię - A.J.S) ) i przywrócić jej godność"26.

„Serbia może iść do przodu - w stronę pokoju, wolności i lepszych dni. A może i wstecz w wojnę, zależność i zacofanie [...]. Serbia w swych rękach dzierży teraźniejszość i przyszłość"27.

Dodatkowo mówca opisuje Serbię jako jednolitą, demokratyczną, równą z pozostałymi republikami, która jest wyzwolicielem, ponieważ nigdy nikogo nie podbijała. Jest wielkim narodem i to nie jest grzech serbski, ale to jest przewaga, której nigdy nie wykorzystywata przeciw innym:

"Serbia jest jednolitym i demokratycznym państwem [...]"28.

"Serbia jest dziś jednolita, równoprawna wobec innych republik i gotowa uczynić wszystko, by polepszyć materialny i społeczny żywot wszystkich swoich obywateli" 29 .

„[...] Serbowie w czasie istnienia swej historii nigdy nie podbijali i eksploatowali innych. Ich narodowy i historyczny cel, przez całą historię, przez dwie wojny światowe, tak jak dzisiaj opiera się na wyzwoleniu. Wiecznie wyzwalali siebie, a kiedy mieli okazję pomagali wyzwalać inne narody" 30

Według polityka Serbia, ale także Jugosławia, jest krajem wielu narodów. Albańczycy, Węgrzy, Czarnogórcy, Muzułmanie, Turcy czują się Jugosłowianami:

„Serbii nigdy nie zamieszkiwali tylko Serbowie [...]. To nie jest ułomność dla Serbii. Szczerze jestem przekonany, że to jest jej zaleta" ${ }^{31}$.

\section{- .....}

22 Govor na predsedništvu SPS, w: S. Milošević, op. cit., s. 35.

Govor u skupštini Srbije, w: S. Milošević, op. cit., s. 128.

24 Govor u Boru, w: S. Milošević, op. cit., s. 68.

25 Govor na skupštini Srbije, w: S. Milošević, op. cit., s. 88; Govor u skupštini Srbije, w: S. Milošević, op. cit., s. 127.

26 Govor na sednici predsedništva SR Srbije - izbor za predsednika, w: S. Milošević, op. cit., s. 24-25.

27 Govor na mitingu u Nišu, w: S. Milošević, op. cit., s. 71.

28 Govor u Boru, w: S. Milošević, op. cit., s. 65.

29 Govor na sednici predsedništva SR Srbije - izbor za predsednika, w: S. Milošević, op. cit., s. 24

30 Ibidem.

31 Ibidem. 
„W Serbii żyje ponad półtora miliona Albańczyków, Węgrów, Czarnogórców, Muzułmanów, Turków itd. [...]. Duża jest liczba małżeństw i rodzin mieszanych, w których przychodzą na świat dzieci, które czują się Jugosłowianami. Serbia nie ukrywa, że obchodzi ją Jugosławia jako wspólna ojczyzna wszystkich naszych narodów. I nie jest to unitaryzm, ale mądre i sprawiedliwe postrzeganie państwa, które leży w interesie wszystkich narodów i narodowości Jugosławii"32.

Oprócz akcentowania jej siły i łagodności, postrzega Serbię także jako umęczone i uciskane państwo, które jest przedmiotem agresji antyserbskich i antyjugosłowiańskich, a kryzys może sprawić, że Serbia stanie się europejską sierotą. Siły działające przeciw Serbii chcą zmniejszyć jej terytorium, zneutralizować jej wojska, naciskać na Serbie poprzez problem Kosowa, przetworzyć ją w peryferyjne państwo bałkańskie, które nie może wpływać na swój los:

„My w Serbii mamy moralne prawo i wymagamy, by wojna się skończyła. Ponieważ Serbia była przedmiotem nadmiernych i wszystkich możliwych ataków, co najczęściej było wyrazem niechęci sił antyserbskich i antyjugosłowiańskich..." ${ }^{33}$.

„.... i galopujący kryzys ekonomiczny, który grozi nam zostaniem największą sierotą europejską ${ }^{34}$. Ten strategiczny kierunek działalności przeciw Serbii oznacza:

1. Redukcje terytorium serbskiego do najmniejszego z możliwych,

2. Zneutralizowanie siły wojskowej Serbii poprzez dyskredytowanie, a jeżeli jest możliwe to poprzez pokonanie JNA,

3. Nakładnie i podżeganie w Serbii poprzez wewnętrzne i zewnętrzne naciski na problem Kosowa,

4. Przekształcanie Serbii [...] w peryferyjne państwo bałkańskie bez możliwości wpływania na swój los i bycie odpornym na zewnętrzne naciski" 35 .

\section{O NARODZIE SERBSKIM}

Naród serbski postrzegany był przez Miloševicia jako mały, patriotyczny, cywilizowany naród, który szanuje swoją przeszłość i jest z niej dumny, który spontanicznie i masowo angażuje się $w$ wydarzenia państwowe ${ }^{36}$. Wielokrotnie podkreślał, że naród serbski włożył bardzo dużo trudu w tworzenie Jugosławii, a najważniejszym celem narodowym jest pokój:

"Jesteśmy małym narodem..." 37.

„Jako patrioci i cywilizowani ludzie zawsze chcemy szanować naszą przeszłość, z której jesteśmy dumni"38.

„Naród serbski poprzez swoją historię włożył dużo wysitku w formowanie Jugosławii. Naturalne i logiczne jest to, że nie może zaakceptować tego, by ten trud został zaprzepaszczony"39.

Ponadto los narodu serbskiego jest w jego rękach, naród ten nie będzie niczyim sługą. Serbowie nie mogą się nikogo bać ani wahać się między pokojem i stabilnością a chaosem i wojną. Zaznacza, że nigdy naród serbski nie budował swoich interesów na niekorzyść innych narodów:40

\section{-....}

32 Govor na skupštini Srbije - izbor za presednika predsedništva SR Srbije, w: S. Milošević, op. cit., s. 29. Ibidem, s. 28.

Govor na mitingu u Novom Sadu, w: S. Milošević, op. cit., s. 82.

Govor u skupštini Srbije, w: S. Milošević, op. cit., s. 128.

36 Ibidem, s. 67

Govor na skupštini Srbije, w: S. Milošević, op. cit., s. 69.

Govor u Boru, w: S. Milošević, op. cit., s. 67.

39 Ibidem, s. 68.

40 Govor na mitingu u Novom Sadu, w: S. Milošević, op. cit., s. 82. 
„[...] nasz los jest w naszych rękach. Nowy porządek światowy nie może oznaczać, że naród który żyje w Jugosławii może być w podrzędnym położeniu, my nie zamierzamy być niczyimi sługami. Chcemy żyć równoprawnie w swoim środowisku, a naszym środowiskiem jest cały świat. Chcemy rozwijać wolny kraj [...]"41.

„Los Serbii jest w rękach jej obywateli i dlatego nikogo nie trzeba się bać. Przekonany jestem, że ogromna większość obywateli nie może sie wahać: czy chce się opowiedzieć za porządkiem, polityczną stabilnością, równoprawnością narodów i ludzi, społeczną prawdą i stworzeniem programu rozwoju kulturowego i ekonomicznego; czy może chce się opowiedzieć za chaosem, przelewem krwi i wojną domową" 42 .

\section{O CHORWACJI, SLOWENII I INNYCH WROGACH}

Z analizy 11 przemówień prezydenta okazuje się, że do „wrogów” możemy zaliczyć zarówno Słowenię, Chorwację, jak i bliżej niesprecyzowanych nieprzyjaciół. Na takie postrzeganie wpływ miały liczne wydarzenia. Po pierwsze, były to demonstracje w Prištinie na terenie Kosowa, które wybuchły w 1981 r. W czasie zamieszek zginęło i zostało rannych wielu mieszkańców tej prowincji - głównie narodowości albańskiej, a polityka S. Miloševicia wobec Albańczyków doprowadziła do represji. A. Koseski uważa, że uciekał się on do tych metod wobec wszystkich, którzy chcieli oderwać od Jugosławii Kosowo. Oddanie Kosowa oznaczałoby przekreślenie tradycji serbskiej, tradycji związanej z bitwą na Kosowym Polu z 1389 r. ${ }^{43}$ Ponadto S. Milošević budował budzącą respekt nacjonalistyczną reputację poprzez obronę interesów serbskiej mniejszości w zdominowanym przez Albańczyków Kosowie - świętym dla Serbów ${ }^{44}$. Skutkiem tego był konflikt serbsko-albański o Kosowo. Po drugie, odłączenie się Słowenii i Chorwacji od Jugosławii, konflikt serbsko-chorwacki o Krainę ${ }^{45}$, który rozpoczął się w 1991 r. od oblężenia Vukovaru, a później miasta Osijek oraz narastający konflikt w Bośni i Hercegowinie między Serbami, Chorwatami i Muzułmanami pozwoliły określić winnych „tragedii narodowej”. Jak zatem S. Milošević opisuje Słowenię, Chorwację i Albańczyków?

Mówiąc o swoich wrogach, starał się wytworzyć poczucie zagrożenia dla całego narodu serbskiego. Słowenia jawiła się jako agresywny i konserwatywny przeciwnik, który obraża godność człowieka i jest zagrożeniem dla praw człowieka:

„[...] Serbia walczyła z siłami przeciwnymi reformie i przeciw Jugosławii, szczególnie poza Serbią [...] konflikt ten najdrastyczniej przebiegał z władzami słoweńskimi. Władza ta jest obrońcą konserwatyzmu w Jugosławii [...] i w socjalistycznych krajach. Jej [Słowenii - A. J.S.] agresja [...] może godzić w godność ludzi [...] Obecna polityka Słowenii nie tylko obraża godność ludzi, ale także zagraża podstawowym prawom człowieka, obywatelom Jugosławii w słoweńskiej części państwa jugosłowiańskiego. Biurokratyczna i agresywna władza słoweńska siłą przerwała więź z narodem z Serbi, i my czyn ten potraktowaliśmy poważnie. [...] pozostaniemy

\section{- •...}

41 Govor u skupštini SRJ prilikom proglašenja ustava SRJ, w: S. Milošević, op. cit., s. 136.

42 Govor u Boru, w: S. Milošević, op. cit., s. 67.

43 A. Koseski, op. cit., s. 177-178. Kosowo uznawane jest przez Serbów za ich terytorium historyczne. W 1389 r. wojska serbskie na czele z księciem Lazarem stoczyły bitwe z Turkami dowodzonymi przez sułtana Murada. Podczas bitwy prawdopodobnie zginęli obaj przywódcy. W 2008 r. Kosowo ogłosiło niepodległość. Zamieszkuje je obecnie 90\% Albańczyków, 5\% Serbów i 5\% innych mniejszości. Serbia nie uznała jego niepodległości, gdyż według konstytucji Serbii z 2006 r. pozostaje ono częścią autonomiczną terytorium Republiki Serbii.

44 S.I. Griffiths, Nationalism and Ethnic Conflict. Threats to European Security, SIPRI Research Report No. 5, Oxford University Press 1993, s. 41.

45 Zamieszkiwało tam ok. 300 tys. Serbów. 
dotąd, aż siły konserwatyzmu [...] ustąpią miejsca demokracji, pokojowi i braterstwu w słoweńskiej polityce" ${ }^{46}$.

Ponadto Stowenia i Chorwacja podtrzymują terror w Kosowie. Z kolei niezidentyfikowany wróg chce, by Serbia stała się państwem wasalnym. Uważał, że wszyscy nieprzyjaciele mobilizują się ${ }^{47}$ przeciw Serbii i chcą narzucić swój dyktat i rozbić Serbię tak, by stali się oni mniejszościami narodowymi:

„[...] gniew w sercu każdego obywatela Serbii wywołuje wspieranie terroru w Kosowie, które pochodzi ze Słowenii i Chorwacji, z tych środowisk, które najgłośniej opowiadają się za demokracją, wolnością [...]"48.

„[...] aby Serbia wróciła tam, gdzie niedawno była - do statusu wasalnego państwa, tylko pod obcym panowaniem"49.

„Proponują nam, być może, najbardziej efektywne środki, by Serbia zrezygnowała z Jugosławii i przyjęła dyktat z północnego zachodu, by rozdarta została na tyle niezależnych państw, ile jest w niej republik. W ten sposób Serbia musiałaby się ostatecznie wyrzec swojego ideału umieszczenia całego narodu serbskiego w jednym państwie, z którym wstąpiła w tworzenie Jugosławii. Serbowie zostaliby wówczas rozdzieleni na wiele państw, a duża część serbskiego narodu stałaby sie mniejszością narodową" 50 .

W przemówieniach występuje: opis wroga, kim jest wróg i co robi. Nieprzyjaciel często pojawia się jako bezosobowa forma ONI i jest przeciwstawiona MY. Innymi określeniami były: Stowenia, Chorwacja, separatystyczny ruch w Kosowie..., Albańscy separatyści, Albańscy szowiniści, a nawet Kłamliwi prorocy. Określenia nadawane wrogom były swojego rodzaju etykietami.

\section{O ALBAŃCZYKACH / KOSOWIE}

W 1989 r. S. Milošević nie pozwolit na utworzenie partii albańskiej; mówit, że w ten sposób Serbia utraciłaby Kosowo ${ }^{51}$. Partie opozycyjne w Serbii oskarżyły go o nieprzestrzeganie praw człowieka w Serbii i Kosowie ${ }^{52}$. Następnym krokiem było zniesienie autonomii Kosowa i Wojwodiny oraz ograniczenie praw zarówno mniejszości albańskiej jak i mniejszości węgierskiej. Albańczycy zaczęli tworzyć sieć szkół podziemnych oraz bojkotowali władze Serbów w Kosowie.

Jednym z najważniejszych priorytetów S. Miloševicia było ustanowienie pokoju i porządku w Kosowie, gdyż w Kosowie włada terror i nienawiść, a przecież Kosowo należy do ziemi jugosłowiańskiej:

„W tym momencie najważniejsza kwestią do rozwiązania jest tworzenie porządku i pokoju w Kosowie. Dla Serbii nie ma bardziej priorytetowego zadania [...]"53.

„Dziś w Kosowie szaleje terror i nienawiść, a Kosowo znajduje sie na naszej Jugosłowiańskiej ziemi54. Do walki przeciw złu w Kosowie nie jest potrzebne oddawanie życia, tak jak kiedyś w Hiszpanii, trzeba tylko wypełnić przysięgę, którą my Jugosłowianie złożyliśmy jedni drugim

\section{-.....}

46 Govor na skupštini Srbije - izbor za presednika predsedništva SR Srbije, w: S. Milošević, op. cit., s. 29.

47 Ibidem, s. 88.

48 Govor na predsedništvu SPS, w: S. Milošević, op. cit., s. 33.

49 Govor na skupštini Srbije, w: S. Milošević, op. cit., s. 88.

50 Ibidem, s. 89

51 J. Guskova, op. cit., t. 1, s. 110

52 Ibidem, s. 446.

53 I.B. Mijatović, op. cit., s. 222.

54 Ibidem, s. 223. 
w 1941 roku, iż chcemy dzielić wszystko w braterstwie i jedności - dobro i zło, zwycięstwo, kłamstwo i biedę, budować "nowy, lepszy świat»" 55 .

Serbów uważał Milošević za kosowskich męczenników. Często wyrażał swoją opinię na temat bitwy kosowskiej, którą bez względu na przeszkody wygrają Serbowie:

„Długa nieobecność tej solidarności, za niekończącym się cierpieniem Serbów i Czarnogórców, w Kosowie jest niezaleczoną raną w ich sercu, jak i w sercu całej Serbii. Nie jest to czas smutku, ale czas na walkę. Ta świadomość zdobywała Serbię [...] i ta świadomość [...] zatrzyma terror w Kosowie i zjednoczy Serbię"56.

„Bitwę o Kosowo wygramy bez względu na przeszkody, które istnieją w kraju i poza nim5

Tę Bitwę o Kosowo przedsięwziął naród, wszyscy obywatele bez względu na narodowość i zawód. Nie ma na świecie bitwy, którą by naród przegrat" 58 .

Aby wzmocnić przekonanie mas, stosuje retoryczne stwierdzenia: bitwa w Kosowie porażką czy zwycięstwem? Odpowiedź ma się sama nasuwać: jest zwycięstwem ${ }^{59}$. Dla prezydenta bitwa na Kosowym Polu jest symbolem bohaterstwa, które inspiruje twórczość, karmi dumę, nie pozwala zapomnieć, że Serbowie byli wojskiem wielkim, odważnym i dumnym - tym samym bitwa ta staje się metaforą. Przytacza często inne metaforyczne stwierdzenia, że Kosowo dla Serbii i Jugosławii jest centrum serbskiej historii, kultury i pamięci. Jest miłością narodu, które ogrzewa jego serce. Jest sercem Serbii a każdy obywatel jest gotowy walczyć o Kosowo. Ponadto przywołuje ważną rolę Serbii, która w Kosowie broniła siebie i Europy:

„Bitwa kosowska zachowuje w sobie jeszcze jeden wielki symbol. Jest to symbol bohaterstwa. Jemu poświęcone są pieśni, tańce, literatura i historia. Bohaterstwo kosowskie już sześć wieków inspiruje nasze jestestwo, karmi naszą dumę, nie pozwala nam zapomnieć, że byliśmy wielką, odważną i dumną armią, jedną z nielicznych, która nie została pokonana"60.

„Niech nikogo nie dziwi, że Serbia tego lata powstała na równe nogi z powodu Kosowa. Kosowo jest samym centrum jej historii, kultury i jej pamięci. Każdy naród ma miłość, która wiecznie grzeje jego serce. Dla Serbii jest to Kosowo. Dlatego też Kosowo pozostanie przy Serbii"61.

„Na tym miejscu w Sercu Serbii, na Kosowym Polu, sześć wieków temu, przed sześciuset laty, wydarzyła się największa bitwa tych czasów"62

„[...] każdy dom w Serbii jest gotowy, by jutro iść do Kosowa [...] Każdy, kto zna historię Serbii i każdy, kto wie, co czują obywatele Serbii, wie, że tak będzie jeżeli kontynuowany będzie terror w Kosowie"63.

„[...] Na Kosowym Polu bohatersko broniła (Serbia - A.J.S) siebie. Broniła także Europy [...]. Dlatego dzisiaj jest to niesprawiedliwe a nawet i niehistoryczne i absurdalne mówić o przynależnosci Serbii do Europy. Ona jest w niej nieprzerwanie, dzisiaj i wcześniej"64.

S. Milošević do wrogów zaliczał także separatystów albańskich. Uważał, między innymi, że wszyscy Albańczycy w Kosowie, którzy szanują innych ludzi, znajdują się na swojej ziemi. Z kolei albańscy szowiniści i ruch separatystyczny uderzają w Serbię i Jugosławię. Dobrzy Albańczycy nie mogą pozwolić złym Albańczykom na konflikt w Kosowie i nie do-

55 Ibidem, s. 222-224

56 I.B. Mijatović, op. cit., s. 222.

57 Ibidem.

58 Ibidem.

59 Govor na sednici predsedništva SR Srbije - izbor za predsednika, w: S. Milošević, op. cit., s. 24.

60 Ibidem, s. 25

61 I.B. Mijatović, op. cit., s. 223.

62 Govor na Gazimestanu, w: S. Milošević, op. cit., s. 23

63 Govor na predsedništvu SPS, w: S. Milošević, op. cit., s. 34.

64 Govor na sednici predsedništva SR Srbije - izbor za predsednika, w: S. Milošević, op. cit., s. 25. 
staną ani piędzi ziemi. S. Milošević podkreślał, że Serbowie będą bronić Kosowa w sposób demokratyczny, zaznaczając przy tym, że albańscy szowiniści mają wsparcie ze Słowenii i Chorwacji:

„Albańczykom z Kosowa mogę powiedzieć, że w Serbii nikomu nie było ciężko żyć tylko dlatego, że nie jest Serbem. Serbia od zawsze była otwarta dla wszystkich - i dla tych, którzy nie mieli dokąd pójść. [...] Wszyscy Albańczycy z Kosowa, którzy wierzą innym ludziom i szanują innych ludzi w Kosowie i Serbii, są w swoim kraju"65.

„Proszę ich, by się zrzeszyli przeciw złu i nienawiści swoich szowinistów, gdyż oni niosą zło nie tylko Serbom i Czarnogórcom ale i własnemu - albańskiemu narodowi. Wstydzą się go przed światem, zawstydzają go przed własnymi dziećmi, obrażają własną godność. W tym imieniu wzywam Albańczyków z całego Kosowa, by o spokojny sen, edukację i beztroską zabawę serbskich i czarnogórskich dziewczynek i chłopców troszczyły się matki albańskie [...]"66.

"Separatystyczny ruch w Kosowie wybrał moment najcięższego kryzysu zaufania w Jugosławii, by wraz ze wsparciem antyserbskich i antyjugosłowiańskich sił w kraju i za granicą, wykonać uderzenie w integralność Serbii i Jugosławii"67.

„Albańscy szowiniści pokazali społeczeństwu swoje rozpaczliwe wysiłki masowego włączenia w walkę Albańczyków z Kosowa [...] Przecież wiedzą [...], że nigdy nie dostaną ani nie zdobędą [...] ani jednej piędzi ziemi serbskiej. Szowinistyczne cele nigdy nie były wznioste"68.

„Albańscy szowiniści także powinni wiedzieć, że Kosowa nie bronimy i nie będziemy bronić ofiarnością Serbów i Czarnogórców, którzy żyją w Kosowie. Kosowa bronimy środkami państwa prawa, które są od nich silniejsze [...]"69.

„W tym sensie wydaje mi się, że wzywanie do demokratycznych żądań, za którymi stoi zamaskowany szowinistyczny ruch w Kosowie, byłoby widoczną hipokryzją"70.

„Tym razem albańscy szowiniści byli agresywniejsi z powodu wsparcia ze strony Stowenii i Chorwacji $[\ldots]^{\prime \prime 71}$.

S. Miloševicia oskarżano o rozpętanie serbskiego nacjonalizmu, a nawet o zapoczątkowanie upadku Jugosławii, uważano go za animatora prześladowań Albańczyków. Nie zgadza się z tymi twierdzeniami M. Waldenberg i nie uważa, by za wyraz podsycania serbskiego nacjonalizmu można było uznać przemówienie S. Miloševicia wygłoszone na wiecu w Belgradzie 19 listopada 1988 r. Postulatem akceptowanym przez S. Miloševicia była rewizja konstytucji z 1974 r. - uniezależnienie Serbii od jej autonomicznych krajów i ograniczenie uprawnień władz autonomicznych w drodze przekazania niektórych kompetencji władzom republiki. Miało to polepszyć położenie Serbów w Kosowie i sprzyjać powrotowi Serbów do Kosowa ${ }^{72}$. Narastający konflikt serbsko-albański w Kosowie przyczynił się do ataków NATO na Serbię w 1999 r.

W latach 1989-1997 S. Milošević był prezydentem Serbii, a gdy nie mógł kandydować na trzecią kadencje postanowił startować w wyborach i został wybrany w 1997 r. na prezydenta Federalnej Republiki Jugosławii i pozostał na tym stanowisku do 2000 r. Jednak utracił de facto poparcie i władze w 1999 r. Podczas wyborów na prezydenta Jugosławii

65 I. B. Mijatović, op. cit., s. 223

66 Ibidem, s. 223.

67 Govor na predsedništvu SPS, w: S. Milošević, op. cit., s. 34.

68 Ibidem.

69 Ibidem.

70 Ibidem

71 Ibidem.

72 M. Waldenberg, Rozbicie Jugosławii. Jugosłowiańskie lustro międzynarodowej polityki, Warszawa 2005, s. 254. 
w pierwszej turze otrzymał 40,23\% głosów, a jego przeciwnik Vojslav Koštunica 48,22\%, co oznaczało przeprowadzenie drugiej tury wyborów. Przeciwstawiała się temu opozycja, twierdząc, że wybory zostały sfałszowane, a na V. Koštunicę oddano 53\% głosów. 28 września Komisja Wyborcza podała ostateczne wyniki: V. Koštunica zebrał 48,96\%, a S. Milošević 38,62\%. Opozycja ponownie protestowała, a na ulicach organizowano demonstracje. Dopiero po przybyciu ministra spraw zagranicznych Rosji, który przeprowadził rozmowę z oboma kandydatami, Sąd Konstytucyjny potwierdził wygraną V. Koštunicy, a S. Milošević w krótkim wystąpieniu telewizyjnym ogłosił rezygnację z urzędu prezydenta i złożył życzenia nowemu prezydentowi ${ }^{73}$. Wybory do parlamentu z października $2000 \mathrm{r}$. okazały się dla SPS Miloševicia także przegrane.

W 2001 r. policja przeprowadziła szturm na jego dom znajdujący się w ekskluzywnej dzielnicy Dedinje w Belgradzie. W lutym 2002 r. stanął przed Międzynarodowym Trybunatem Karnym ds. Zbrodni Wojennych w byłej Jugosławii w Hadze ${ }^{74}$. Postawiono mu sześćdziesiąt sześć zarzutów. Obarczano go odpowiedzialnością za exodus i prześladowanie ludności albańskiej z terenów Kosowa w 1999 r. Wydarzenia te uznane zostały za zbrodnie przeciwko ludzkości oraz pogwałcenie praw i zwyczajów wojny, prześladowanie na tle politycznym, rasowym i religijnym i za deportacje oraz o ludobójstwo w czasie wojny w Bośni oraz o zbrodnie przeciw ludzkości w czasie wojny w Chorwacji ${ }^{75}$. Slobodan Milošević został znaleziony martwy w więziennej celi 11 marca 2006 r.

Warto zaznaczyć, że sam S. Milošević także Trybunał uznawał za instytucję nielegalną i w związku z tym w 2001 r. odrzucit propozycję korzystania z obrońcy podczas procesu. Podkreślał, że chodzi mu o obronę narodu serbskiego, a sąd wykorzystał jako trybunę polityczną, umożliwiającą mu przekonanie swych rodaków, że w Hadze wytoczono proces Serbii i jej historii, a nie jemu6. Pierwsze jego oświadczenie przed trybunałem brzmiato: „, nie uznaję tego sądu, ten sąd jest nielegalny, a oskarżenia są fałszywe”. Jak uważa S. Drakulić, interesowały go jedynie polityczne przemowy ${ }^{77}$. Zaprzeczył wszystkim zarzutom o przestępstwa. Nawiązując do porozumienia z Dayton z 1995 r., o wojnie w Bośni powiedział na przykład, że zaprowadzał tam pokój, nie wojnę. Po bombardowaniu w 1999 r. przez NATO S. Milošević gratulował Serbom zwycięstwa w wojnie ${ }^{78}$. Był złośliwy. Mówił, że B. Clinton, bombardując ambasadę Chin w Serbii, chciał jako pierwszy w historii zbombardować ich terytorium ${ }^{79}$. O zachodnich przywódcach powiedział, że są hipokrytami, którzy najpierw zawierali z nim porozumienia - wtedy nie był zbrodniarzem wojennym, ale czynnikiem stabilizacji. Kiedy nie chciał zaspokajać ich żądań i życzeń, nie chciał stać się ich niewolnikiem, jego kraj został zbombardowany, a jego ogłoszono zbrodniarzem wojennym. Powtarzał, że walczył o wolność i niepodległość oraz przeciw międzynarodowemu terroryzmowi ${ }^{80}$.

Na koniec warto przytoczyć słowa brytyjskiego historyka Erica Hobsbawma: „widoczny wybuch separatyzmu w okresie 1988-1992, najprościej więc określić można jako niedokończone sprawy z lat 1918-1921"81. Tym samym, analizowane przemówienia pokazują

3 J. Guskova, op. cit., s. 352.

4 A. Koseski, op. cit., s. 174

75 J. Nowakowska-Małusecka, Odpowiedzialność karna jednostek za zbrodnie popełnione w byłej Jugosławii i Rwandzie, Katowice 2000, s. 140-141.

76 M. Waldenberg, op. cit., s. 376-378.

77 S. Drakulić, op. cit., s. 148.

78 Ibidem, s. 148-149.

79 A. Koseski, op. cit., s. 185

80 S. Drakulić, op. cit., s. 151

81 E. Hobsbawm, Narody i nacjonalizm po 1780 r. Program, mit, rzeczywistość, tłum. J. Maciejczyk, M. Starnowski, Warszawa 2010, s. 174 
narastający nacjonalizm S. Miloševicia i pozwalały przewidzieć, jak może zakończyć się populistyczno-propagandowa retoryka przywódcy Serbów. Ponadto o nacjonalizmie i propagandowej formie tekstów prezydenta świadczą także liczne środki językowe. Przykładem mogą być częste powtórzenia słów kluczowych takich, jak: Serbia, Jugosławia, naród, państwo, Kosowo, pokój i demokracja. Do innych określeń zaliczono słowa takie, jak: narody i narodowości, jugosłowiańskie narody, wspólna ojczyzna, wielonarodowościowa ojczyzna, naród serbski, rozwiązanie serbskiej kwestii narodowej, ochotnicy, godność, jednolita Serbia, bitwa o Kosowo, Kosowe Pole, albańscy szowiniści, terror w Kosowie. Słowa te przybliżają odbiorcom komunikatów S. Miloševicia kwestie pozytywne i negatywne, a także utrwalają w ich świadomości narzucony obraz państwa, narodu i rzeczywistości. Ponadto wśród słownictwa wykorzystanego przez przywódce znalazły się liczne superlatywy (np.: najbardziej efektywny, najważniejszy, największy), słownictwo pozytywne (wolność, zgoda, solidarność) i słownitwo negatywne (kryzys, chaos). Zastosowanie powyższych środków językowych umożliwiło S. Miloševiciowi nadawanie ważności tekstom, nakłanianie do określonych zachowań, czy też zafałszowywanie rzeczywistości. Zastosowanie zaimka my/nasz - oni (My jesteśmy małym narodem, nasz wspólny...), odwoływanie się do powszechności sądów poprzez kolektywy my, każdy, wszyscy, nasze; używanie skrzydlatych stów (np.: Bitwa Kosowska [...] jest symbolem bohaterstwa) powodowały przybliżenie emocjonalne i zdobycie przychylności narodu dla prezydenta i jego dążeń.

\section{NATIONALISM IN SLOBODAN MILOŠEVIĆ'S SPEECHES}

\section{Summary}

The fall of Yugoslavia showed economical, national, ideological and political problems. Thus, there was a strong rise of hidden nationalisms among nations living on the same territory, such as Slovenian, Croatian, Bosnian, Serbian, Montenegrin and Macedonian from 1980'.

The aim of the article is to show how Slobodan Milošević's nationalism was raising in his speeches in the period between 1988 (when he came to power) and 1992 (the new constitution of FRY was established). The author analyzed eleven speeches made during the debates in the Serbian Parliament, during sessions of the Socialist Party of Serbia and during meetings with people in such cities as Gazimstan, Belgrade, Novi Sad, Bor and Niš. In his speeches Milošević raised such subjects as the question of Yugoslavia, the question of Serbian nation living on the whole territory of Yugoslavia, the role of Serbia in the creation of Yugoslavia. Additionally, he was blaming "enemies" (such as Slovenia, Croatia, Albanians from Kosovo) for collapse of Yugoslavia and the war in the 1990'. He was using a language of populism and propaganda to enhance his goals and tried to be emotionally close to his nation.

Keywords: Slobodan Milošević, hidden nationalisms, Yugoslavia, language of populism and propaganda 